\title{
Perancangan Desain Sistem Informasi Geografis Pemetaan Desa Mandiri Energi Kec. Pangalengan Kab. Bandung
}

\author{
R. A. E. Virgana ${ }^{1}$, Dani Hamdani ${ }^{2}$ \\ ${ }^{1,2}$ Universitas Widyatama, Kota Bandung, Indonesia, \\ Program Studi Sistem Informasi, FT Universitas Widyatama, Bandung, Indonesia \\ e-mail: 1rae.virgana@widyatama.ac.id, ${ }^{2}$ dani.hamdani@widyatama.ac.id
}

\begin{abstract}
Abstrak
Kecamatan Pangalengan mempunyai keunikan dan kekhasan, seperti faktor ketinggian, kelompok pertanian, kelompok perternakan, perkebunan rakyat maupun perkebunan besar/negara. Permasalahannya belum ada peta data sebaran sumber energi di Kecamatan Pangalengan, seperti banyaknya peternakan sapi hampir semuanya memiliki reaktor biogas, juga perkebunan rakyat yang tersebar hampir disetiap desa dimana terdapat potensi energi biomassa, danau seperti situ Cileunca yang aliran airnya digunakan oleh sekitar 3 perusahaan listrik negara (Indonesia Power) sampai di daerah Cikalong, serta perkebunan besar/negara yang beroperasi di Kecamatan Pangalengan ada ratusan hektar, tetapi apakah hasil biomassa perkebunannya sudah dioptimalkan untuk kepentingan energi. Metode yang digunakan adalah geoprocessing melakukan overlay beberapa peta dan data sehingga data ditarik kesimpulan informasinya, hasil penelitian ini berupa peta sebaran potensi-potensi sumber daya hayati yang dapat digunakan sebagari sumber energi, dan dampak yang diharapkan semoga masyarakat dan aparatur pemerintah di Kecamatan Pangelangan lebih memahami potensi energi mandiri didaerahnya.
\end{abstract}

Kata kunci: SIG, Pemetaan, Energi, Pangalengan

\begin{abstract}
Pangalengan District has its uniqueness and uniqueness, such as the height factor, agricultural groups, livestock groups, community plantations or large / state plantations. The problem is that there is no map of the distribution of energy sources in Pangalengan Subdistrict, as many cattle farms almost all have biogas reactors, as well as smallholder plantations that are scattered in almost every village where there is biomass energy potential, lakes such as Cileunca where the water flow is used by around 3 state electricity companies (Indonesia Power) reached the Cikalong area, and there are hundreds of hectares of large / state plantations operating in Pangalengan District, but whether the yield of plantation biomass has been optimized for energy purposes. The method used is geoprocessing to overlay several maps and data so that the data conclusions drawn information, the results of this study in the form of a distribution map of potential biological resources that can be used as an energy source, and the expected impact hopefully the community and government officials in Pangelang District better understand the potential for independent energy in the area..
\end{abstract}

Keywords: GIS, Mapping, Energy, Pangalengan 


\section{Pendahuluan}

Energi terbarukan merupakan harapan kita semua, energi yang tidak terbarukan seperti minyak dan gas semakin tipis dan sulit di eksplorasi, harga minyak dan gas yang semakin melambung, dan Indonesia sudah tidak sebagai produsen minyak dan gas, malah sebagai importir minyak dan gas, membuat pemerintah susah payah untuk dapat menstabilkan harga minyak dan gas. Harapan energi lain selalu ada, energi yang hijau dan bersih, tanpa menimbulkan polusi dan emisi baik sebelum dan sesudah produksi, maupun saat digunakan adalah energi terbarukan. Energi di negeri kita Indonesia, sangat luar biasa banyak sekali, dengan posisi negari kita tercinta ini ada di garis khatulistiwa maka sinar matahari full 12 jam sehari, energi matahari inilah yang diserap oleh banyak makhluk hidup, manusia, binatang, dan tumbuhan [1]. Energi hijau terserap oleh mahluk hidup, dan terserap sebagai energi untuk mahluk hidup tersebut, dan sebagian menjadi residu atau kotoran atau sisa metabolisme mahluk tersebut inilah yang disebut biomassa atau bioenergi. Salah satu pengolahan biomassa ini adalah biogas yang akan menjadi energi berbentuk gas yang dapat digunakan oleh manusia [2]. Proses dari pembentukan energi dari biomassa ini sendiri, macamnya banyak sekali untuk dapat membangkitkan energi, dari mulai sistem pembakaran (boiler) sampai dengan sistem fermentasi, dan sebagainya [3][4].

Area penelitian dalam studi kasus ini adalah Kecamatan Pangalengan, Kabupaten Bandung, di Provinsi Jawa Barat, kecamatan ini sudah sangat terkenal dari zaman dahulu sampai sekarang sebagai sentra perkebunan rakyat maupun swasta besar/negara, memiliki beberapa danau/situ besar sebagian sudah digunakan oleh beberapa PLTA (Indonesia Power), penghasil susu sapi terbesar di Jawa Barat, malah pernah disebut terbesar di Indonesia, dengan jumlah populasi sapi 12.000 ekor, dan beberapa tahun yang lalu jumlahnya pernah lebih dari 24.000 ekor, dikarenakan ada kejadian kelangkaan daging di Indonesia dan harga daging sangat melambung, dan menggiurkan para peternak untuk melepas sapi perah mereka, sehingga populasi sapi perah di kecamatan ini menurun, tetapi dengan jumlah 12.000 ekor sapi perah tetap merupakan populasi yang sangat besar. Potensi energi biomassa ini yang akan di eksplorasi oleh peneliti, kesadaran bahwa kotoran sapi perah dapat menjadi energi biogas, sebenarnya sudah di kampanyekan oleh pemerintah dan pihak-pihak lain, tetapi tidak maksimal dengan alasan bahwa sumber energi lain ada, seperti gas $3 \mathrm{~kg}$ terdistribusikan sampai ke desa-desa terpencil ini. Tujuan penelitian ini adalah untuk dapat mensurvei dan memetakan sebaran peternak sapi, perkebunan, sumber daya hayati di Kecamatan Pangalengan, Kabupaten Bandung, baik yang sudah mempunyai instalasi biogas maupun yang belum memilikinya, sehingga bisa tergambarkan potensi energinya, alasan-alasan peternak tidak mau membuat instalasi biogas, dan sebagainya [5].

\section{Kajian Pustaka}

Penelitian ini terdiri dari serangkaian tindakan atau langkah-langkah yang diperlukan untuk secara efektif melakukan penelitian dan urutan yang diinginkan dari langkahlangkah tersebut. Untuk menghindari masalah yang timbul dari proses penelitian, maka diperlukan prosedur-prosedur yang sebelumnya diperhitungkan.

Menurut C. R. Kothari [6], langkah-langkah detail proses untuk memberikan panduan prosedural yang berguna dalam proses penelitian adalah sebagai berikut:

a. Formulating The Research Problem

b. Extensive Literature Survey

c. Development Of Working Hypotheses 
d. Preparing The Research Design

e. Determining Sample Design

f. Collecting The Data

g. Execution Of The Project

h. Final Reports

Sistem Informasi Geografis : SIG merupakan sistem penanganan data keruangan [7], SIG adalah sistem berbasis komputer yang digunakan untuk memasukan, menyimpan, mengelola, menganalisis dan mengaktifkan kembali data yang mempunyai referensi keruangan untuk berbagai tujuan yang berkaitan dengan pemetaan dan perencanaan Burrough (1986). SIG adalah sistem yang terdiri dari perangkat keras, perangkat lunak, data, manusia (brainware), organisasi dan lembaga yang digunakan untuk mengumpulkan, menyimpan, menganalisis, dan menyebarkan informasi-informasi mengenai daerah-daerah di permukaan bumi - Chrisman (1997). GIS can be seen as a system of hardware, software and procedures designed to support the capture, management, manipulation, analysis, modeling and display of spatially-referenced data for solving complex planning and management problems.

Nama-nama lain SIG [8] :

a. Sistem Informasi Lahan (Land Information System = LIS)

b. Pemetaan Terotomatis dan Pengelolaan Fasilitas (AM/FM =Automated Mapping and Facilities Management)

c. Sistem Informasi Lingkungan (Enviromental Information System = EIS)

d. Sistem Informasi Sumber Daya (Resources Information System= RIS)

e. Sistem Informasi Perencanaan (Planning Information System = PIS)

f. Sistem Penanganan Data Keruangan (Spatial Data Handling System = SDHS)

g. Nama lain dari Disiplin Ilmu SIG:- Geomatic- Geoinformatic- Geospatial Information Science

Data / Informasi Geografis [9] :

a. Survei lapanganPengukuran fisik (land marks), pengambilan sampel (polusi air), pengumpulan data non-fisik (data sosial, politik, ekonomi dan budaya).

b. Sensus Dilakukan dgn pendekatan kuesioner, wawancara dan pengamatan; pengumpulan data secara nasional dan periodik (sensus jumlah penduduk, sensus kepemilikan tanah).

c. Statistik merupakan metode pengumpulan data periodik/per-interval-waktu pada stasiun pengamatan dan analisis data geografi tersebut. contoh: data curah hujan.

d. TrackingMerupakan cara pengumpulan data menurut periode tertentu utk tujuan pemantauan atau pengamatan perubahan. contoh: kebakaran hutan, gunung meletus, debit air sungai.

e. Penginderaan jarak jauh (inderaja atau Remote Sensing)Merupakan ilmu dan seni untuk mendapatkan informasi suatu obyek, wilayah atau fenomena melalui analisis data yang diperoleh dari sensor pengamat tanpa harus kontak langsung dgn obyek, wilayah atau fenomena yg diamati

Dalam rangka ketahanan energi, limbah peternakan dapat menjadi sumber bahan baku bahan bakar hewani (bio-energi) seperti sisa kotoran sapi [10]. Kebijakan penyediaan bahan baku bioenergi dilakukan dengan beberapa tahapan sebagai berikut :

a. Jangka Pendek, Pengembangan/intensifikasi peternakan yang sudah ada : peternakan sapi di Kecamatan Pangalengan, Kabupaten Bandung. 
b. Jangka Menengah, Mengembangkan dan mengintensifkan peternakan. Mengkaji dan mengembangkan daerah peternakan potensial penghasil bioenergi, untuk sebagian dapat di implementasikan praktis instalasi bioenergi-nya.

c. Jangka Panjang, Pengkajian dan pengembangan daerah peternakan potensial penghasil bioenergi yang sudah berhasil berjalan semua.

\section{Metode Penelitian}

\section{a. Formulating The Research Problem}

Desa Mandiri Energi adalah harapan untuk menjadi desa yang sejahtera masyarakatnya dan sehat lingkungannya, Kecamatan Pangalengan dengan ketinggian antara 1000 sampai 1800 mdpl mempunyai banyak potensi, seperti perkebunan rakyat dan pemerintah seperti perkebunan teh, kopi, cengkeh dan sebagainya ratusan hektar mempunyai bahan sebagai bahan energi BioMassa, melimpahnya air sungai, beberapa danau seperti danau Cileunca yang luas, adanya 2 PLTA yaitu PLTA Plengan 6,87 MW dan PLTA Lamajan 19,56 MW, bahkan Kecamatan Pangalengan mempunyai PLTU Cibolang dekat dengan pemandian air panas Cibolang, sepertinya Kecamatan Pangalengan tidak akan kekurangan energi khususnya listrik, energi lain bisa didapatkan yaitu BioGas dari peternakan sapi perah, dari data terakhir sejumlah 16.001 ekor sapi perah yang ada, ini merupakan potensi strategis yang menyebar diberbagai rumah peternak sapi di Kecamatan Pangalengan, masalah penelitian ini mempunyai memetakan energi-energi mandiri yang tersebar di Kecamatan Pangalengan, semoga bisa mendapatkan gambaran potensi energinya.

b. Extensive Literature Survey

Telah dibahas dibagian kajian pustaka.

c. Development Of Working Hypotheses

Hipotesa dalam penelitian ini adalah bahwa beberapa desa-desa di Kecamatan Pangalengan mempunyai potensi sebagai Desa Mandiri Energi.

d. Preparing The Research Design

Persiapan pengembangan sistem informasi geografis dengan indikasi grafis menggunakan metode penelitian C.R. Kothari, dengan metode geoprocessing, menggunakan tools Quantum GIS (Geographic Information System), semoga untuk laporan selanjutnya sudah dapat tergambarkan layer-layer geografis berkaitan dengan Desa Mandiri Energi di Kecamatan Pangalengan.

\section{e. Determining Sample Design}

Contoh perancangan indikasi geografis diharapkan bisa menggambarkan potensi desa mandiri energi di Kecamatan Pangalengan, tampak pada Gambar 1., merupakan peta tematik kecamatan Pangalengan, perubahan warna pada setiap polygon menandakan perbedaan desa-desa, dengan peta seperti berikut: 


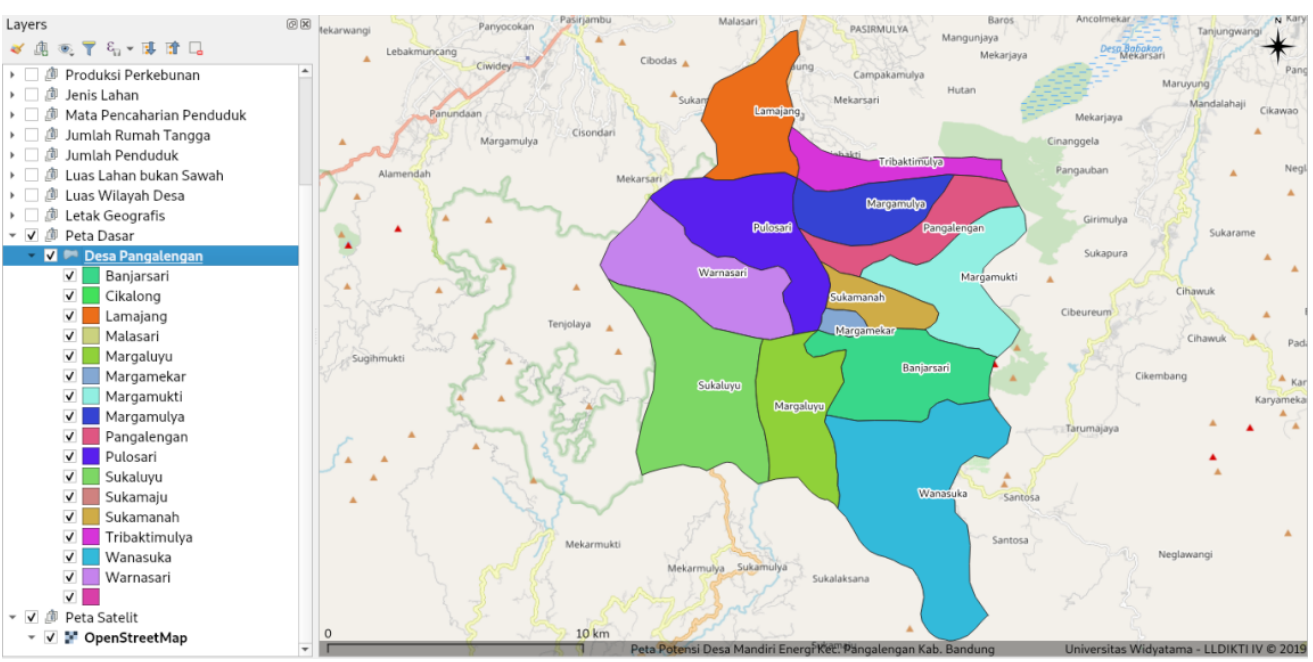

Gambar 1. Peta desa-desa di Kecamatan Pangalengan

\section{f. Collecting The Data}

Contoh data-data yang telah didapat, yaitu luas lahan kering menurut jenis pengunaannya tampak pada Tabel 1 . dan luas dan produksi tanaman perkebunan menurut jenis komoditas pada Tabel 2., akan digunakan dalam penelitian ini sebagai berikut :

Tabel 1. Luas Lahan Kering Menurut Jenis Penggunaannya (hektar)

\begin{tabular}{|c|c|c|c|c|c|c|c|c|c|c|c|c|}
\hline & DESA & KECAMATAN & KABUPATEN & PROPINSI & luasswhha & luasprkbha & luashutnha & luasteglha & luaskolmha & luaskpdgha & luassituha & luaslainha \\
\hline 1 & Pulosari & Pangalengan & Bandung & Jawa Barat & 3.40 & 437.12 & 3873.93 & 253.19 & 0.15 & 30.93 & 60.01 & 270.8 \\
\hline 2 & Warnasari & Pangalengan & Bandung & Jawa Barat & 0.00 & 314.61 & 1352.27 & 529.12 & 0.12 & 4.17 & 65.00 & 30.28 \\
\hline 3 & Sukaluyu & Pangalengan & Bandung & Jawa Barat & 0.00 & 956.10 & 328.51 & 176.59 & 0.56 & 7.76 & 1.00 & 210.4 \\
\hline 4 & Margaluyu & Pangalengan & Bandung & Jawa Barat & 0.00 & 470.00 & 275.88 & 298.64 & 2.19 & 9.12 & 3.00 & 16.5 \\
\hline 5 & Margamukti & Pangalengan & Bandung & Jawa Barat & 0.00 & 536.41 & 1070.62 & 822.00 & 24.53 & 17.87 & 5.44 & 10.29 \\
\hline 6 & Sukamanah & Pangalengan & Bandung & Jawa Barat & 0.00 & 42.00 & 290.04 & 187.07 & 5.61 & 4.72 & 2.50 & 18.2 \\
\hline 7 & Margamekar & Pangalengan & Bandung & Jawa Barat & 0.00 & 73.00 & 0.00 & 423.96 & 4.41 & 25.54 & 10.63 & 176.26 \\
\hline 8 & Banjarsari & Pangalengan & Bandung & Jawa Barat & 0.00 & 1263.16 & 529.66 & 393.12 & 4.11 & 6.53 & 33.87 & 35.68 \\
\hline 9 & Lamajang & Pangalengan & Bandung & Jawa Barat & 836.64 & 6.50 & 1526.36 & 1297.53 & 13.86 & 2.46 & 1.00 & 171.92 \\
\hline 10 & Tribaktimulya & Pangalengan & Bandung & Jawa Barat & 78.81 & 0.00 & 138.89 & 155.52 & 0.34 & 7.60 & 0.00 & 10.0 \\
\hline 11 & Margamulya & Pangalengan & Bandung & Jawa Barat & 42.51 & 618.00 & 129.80 & 298.64 & 2.19 & 9.12 & 0.00 & 37.6 \\
\hline 12 & Pangalengan & Pangalengan & Bandung & Jawa Barat & 0.00 & 201.30 & 47.30 & 118.56 & 1.06 & 5.96 & 0.00 & 17.7 \\
\hline 13 & Wanasuka & Pangalengan & Bandung & Jawa Barat & 0.00 & 999.00 & 2950.59 & 393.12 & 4.11 & 6.53 & 8.00 & 100.12 \\
\hline
\end{tabular}

Tabel 2. Luas dan Produksi Tanaman Perkebunan Menurut Jenis Komoditas

\begin{tabular}{|c|c|c|c|c|c|c|c|c|c|c|c|c|}
\hline & DESA & KECAMATAN & KABUPATEN & PROPINSI & relf: & & prokopiha & prokopikw & procengkha & procengkkw & protehha & protehkw \\
\hline 1 & Banjarsari & Pangalengan & Bandung & Jawa Barat & ... & $\ldots$ & 1 & 14 & 0 & 0 & 1256.00 & 117405.00 \\
\hline 2 & Lamajang & Pangalengan & Bandung & Jawa Barat & ... & $\ldots$ & 93 & 24552 & 0 & 0 & 0.00 & 0.00 \\
\hline 3 & Margaluyu & Pangalengan & Bandung & Jawa Barat & ... & $\ldots$ & 63 & 1310 & 0 & 0 & 447.00 & 36748.00 \\
\hline 4 & Margamekar & Pangalengan & Bandung & Jawa Barat & ... & $\ldots$ & 0 & 0 & 0 & 0 & 20.00 & 1870.00 \\
\hline 5 & Margamukti & Pangalengan & Bandung & Jawa Barat & ... & $\ldots$ & 50 & 1150 & 0 & 0 & 533.00 & 45993.00 \\
\hline 6 & Margamulya & Pangalengan & Bandung & Jawa Barat & ... & ... & 220 & 11618 & 0 & 0 & 615.00 & 53068.00 \\
\hline 7 & Pangalengan & Pangalengan & Bandung & Jawa Barat & ... & $\ldots$ & 0 & 0 & 0 & 0 & 200.00 & 17258.00 \\
\hline 8 & Pulosari & Pangalengan & Bandung & Jawa Barat & ... & $\ldots$ & 441 & 23285 & 0 & 0 & 381.00 & 31322.00 \\
\hline 9 & Sukaluyu & Pangalengan & Bandung & Jawa Barat &.. & $\ldots$ & 104 & 2163 & 0 & 0 & 1137.00 & 44104.00 \\
\hline 10 & Sukamanah & Pangalengan & Bandung & Jawa Barat & ... & $\ldots$ & 66 & 2264 & 0 & 0 & 48.00 & 4487.00 \\
\hline 11 & Tribaktimulya & Pangalengan & Bandung & Jawa Barat & ... & $\ldots$ & 84 & 126 & 0 & 0 & 0.00 & 0.00 \\
\hline 12 & Wanasuka & Pangalengan & Bandung & Jawa Barat & ... & $\ldots$ & 84 & 1747 & 0 & 0 & 999.00 & 82128.00 \\
\hline 13 & Warnasari & Pangalengan & Bandung & Jawa Barat & ... & $\ldots$ & 231 & 693 & 14 & 980 & 51.00 & 4193.00 \\
\hline
\end{tabular}


Tabel 2. Jumlah Ternak Besar

\begin{tabular}{l|l|l|l|l|r|r|r|r|}
\multicolumn{2}{|c|}{ DESA } & KECAMATAN & KABUPATEN & PROPINSI & jumsapi & jumsapiper & jumkerbau & jumkuda \\
\hline 1 & Pulosari & Pangalengan & Bandung & Jawa Barat & 103 & 1275 & 0 & 0 \\
\hline 2 & Warnasari & Pangalengan & Bandung & Jawa Barat & 0 & 1334 & 0 & 0 \\
\hline 3 & Sukaluyu & Pangalengan & Bandung & Jawa Barat & 0 & 449 & 0 & 0 \\
\hline 4 & Margaluyu & Pangalengan & Bandung & Jawa Barat & 0 & 1042 & 0 & 0 \\
\hline 5 & Margamukti & Pangalengan & Bandung & Jawa Barat & 0 & 2589 & 0 & 1 \\
\hline 6 & Sukamanah & Pangalengan & Bandung & Jawa Barat & 16 & 1060 & 0 & 0 \\
\hline 7 & Margamekar & Pangalengan & Bandung & Jawa Barat & 0 & 4647 & 0 & 7 \\
\hline $\mathbf{8}$ & Banjarsari & Pangalengan & Bandung & Jawa Barat & 0 & 163 & 0 & 0 \\
\hline 9 & Lamajang & Pangalengan & Bandung & Jawa Barat & 45 & 0 & 12 & 0 \\
\hline 10 & Tribaktimulya & Pangalengan & Bandung & Jawa Barat & 0 & 876 & 0 & 0 \\
\hline 11 & Margamulya & Pangalengan & Bandung & Jawa Barat & 0 & 1014 & 6 & 0 \\
\hline 12 & Pangalengan & Pangalengan & Bandung & Jawa Barat & 0 & 788 & 2 & 0 \\
\hline 13 & Wanasuka & Pangalengan & Bandung & Jawa Barat & 60 & 764 & 0 & 0
\end{tabular}

\section{g. Execution Of The Project}

Dibahas dibagian hasil dan pembahasan

\section{h. Final Reports}

Makalah ini bagian dari final reports

\section{Hasil dan Pembahasan}

Setelah data dikumpulkan, di analisa, di proses secara geoprocessing, maka hasil keluaran data akan diproses menjadi indikasi geografis, pada Gambar 2. tampak pada peta tersebut sebaran luas wilayah setiap desa dalam satuan hektar, pada warna peta tampak semakin warnanya semakin gelap berarti desa yang bersangkutan semakin luas wilayahnya, dan berbanding terbalik bila warna peta semakin putih, maka luas wilayah semakin kecil, sebagai berikut :

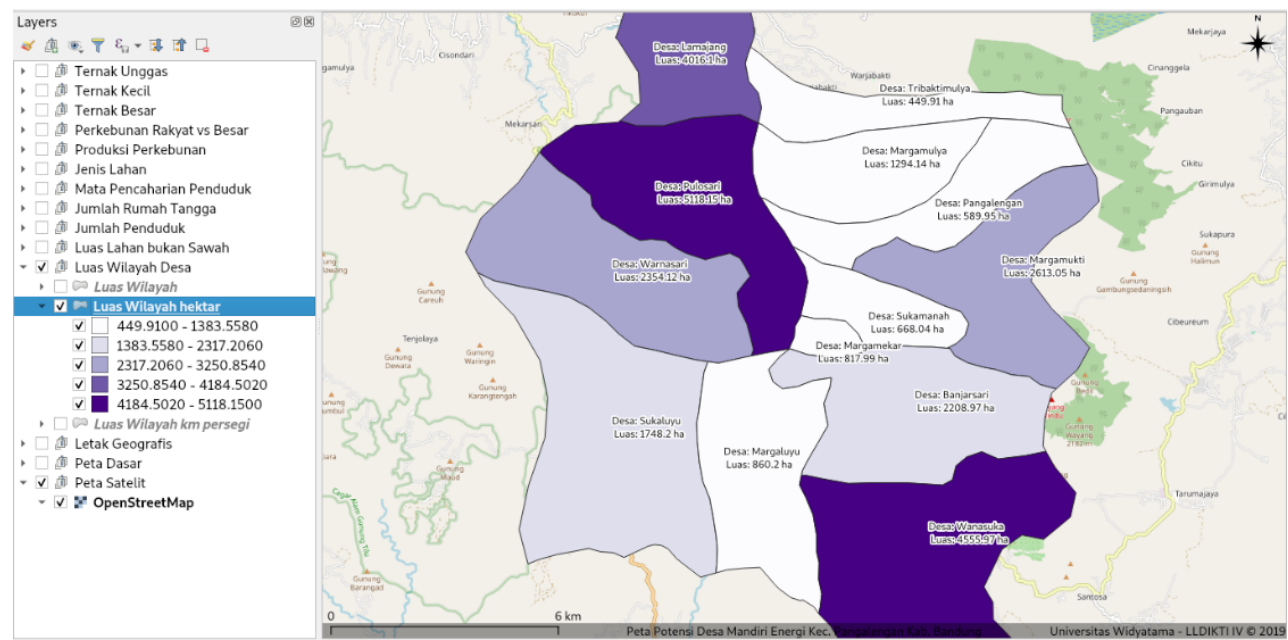

Gambar 2. Peta sebaran luas wilayah setiap desa dalam hektar

Pada Gambar 3. merupakan peta dengan informasi lahan bukan sawah, informasinya adalah membandingkan luas non sawah dan luas non pertanian dalam satuan hektar, data berbentuk label dan grafik batang warna merah menandakan luas non sawah dan warna putih menandakan luas non pertanian, peta Gambar 3. sebagai berikut : 


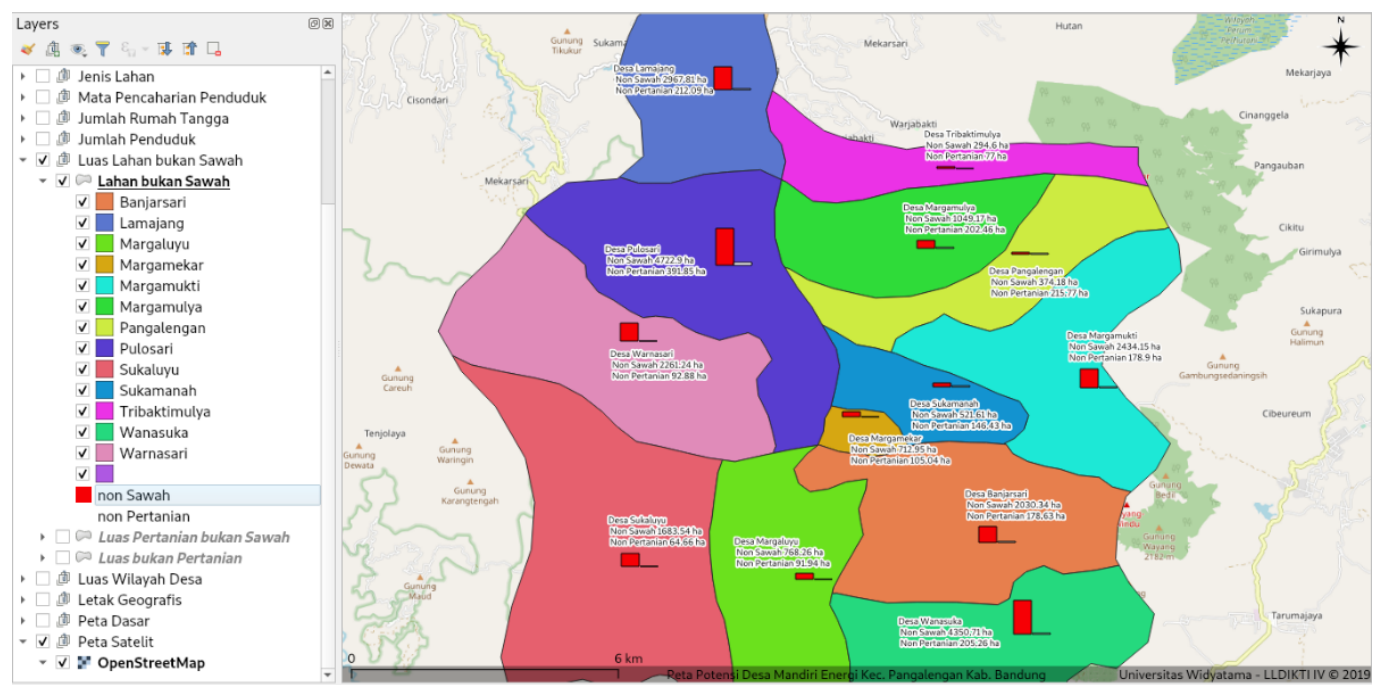

Gambar 3. Peta grafik batang membandingkan luas lahan bukan sawah dengan non pertanian dalam hektar

Pada Gambar 4. merupakan peta sebaran luas pertanian bukan sawah dalam hektar, lahan bukan sawah ini bisa perkebunan, ataupun danau, akan dijelaskan oleh peta-peta lainnya, warna polygon semakin merah menandakan bahwa desa tersebut memiliki luas pertanian bukan sawah semakin besar, dan warna polygon peta memudar bahkan putih menandakan luas pertanian bukan sawah di desa-desa tersebut semakin kecil.

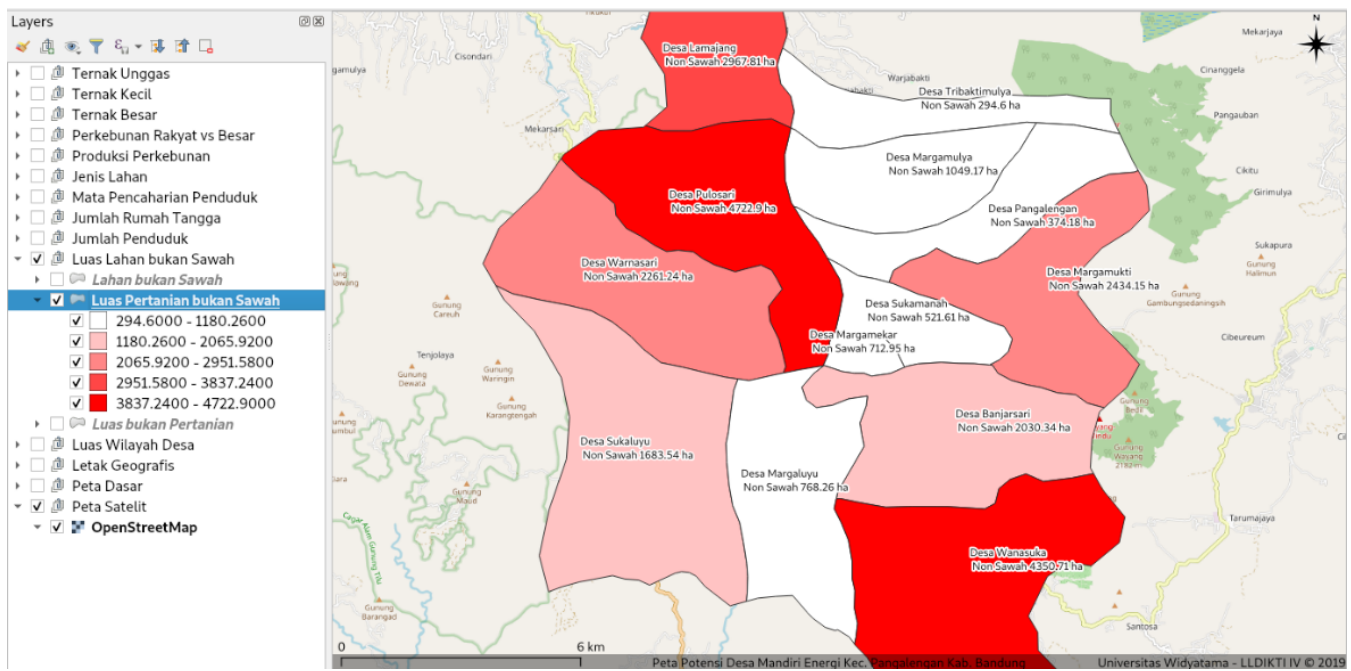

Gambar 4. Peta sebaran luas pertanian bukan sawah dalam hektar

Pada Gambar 5. merupakan peta sebaran luas bukan pertanian dalam hektar, artinya peta ini menunjukkan bahwa area-area di desa tersebut yang bukan pertanian berapa luasnya, bukan pertanian bisa berarti digunakan lapang, danau, peternakan, semakin warnanya ungu gelap menandakan bahwa area desa tersebut memiliki area bukan pertanian yang luas, dan berbanding terbalik bila polygon berwarna ungu semakin pudar bahkan putih menandakan area pertanian yang luas. 


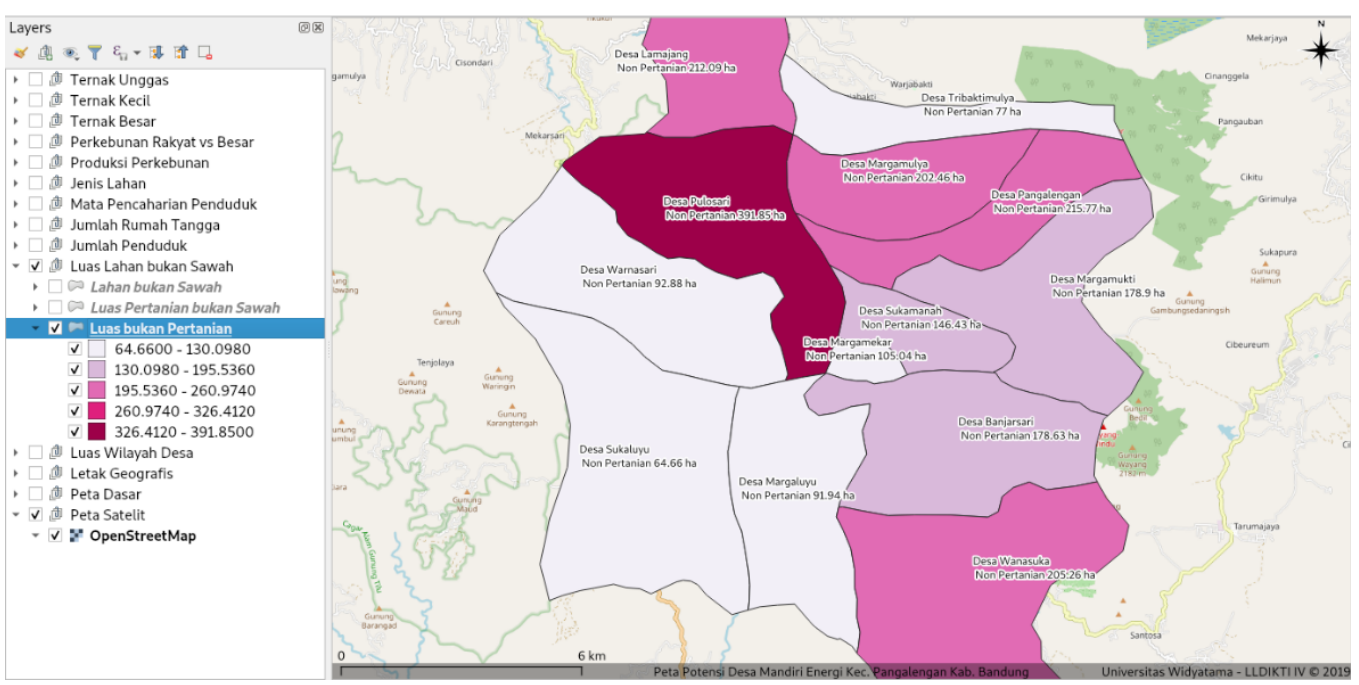

Gambar 5. Peta sebaran luas bukan pertanian dalam hektar

Pada Gambar 6. merupakan peta berbasis grafik perbandingan penggunaan jenis lahan di setiap desa yang ada di kecamatan pangelangan, lahan bisa berarti : sawah, perkebunan, hutan, tegalan, kolam, padang, danau, sebagai contoh pada Desa Pulosari yang polygon-nya berwarna coklat, ada grafik berwarna putih menandakan bahwa hutan di Desa Pulosari ini sangat luas dibandingkan dengan bentuk-bentuk lahan lainnya.

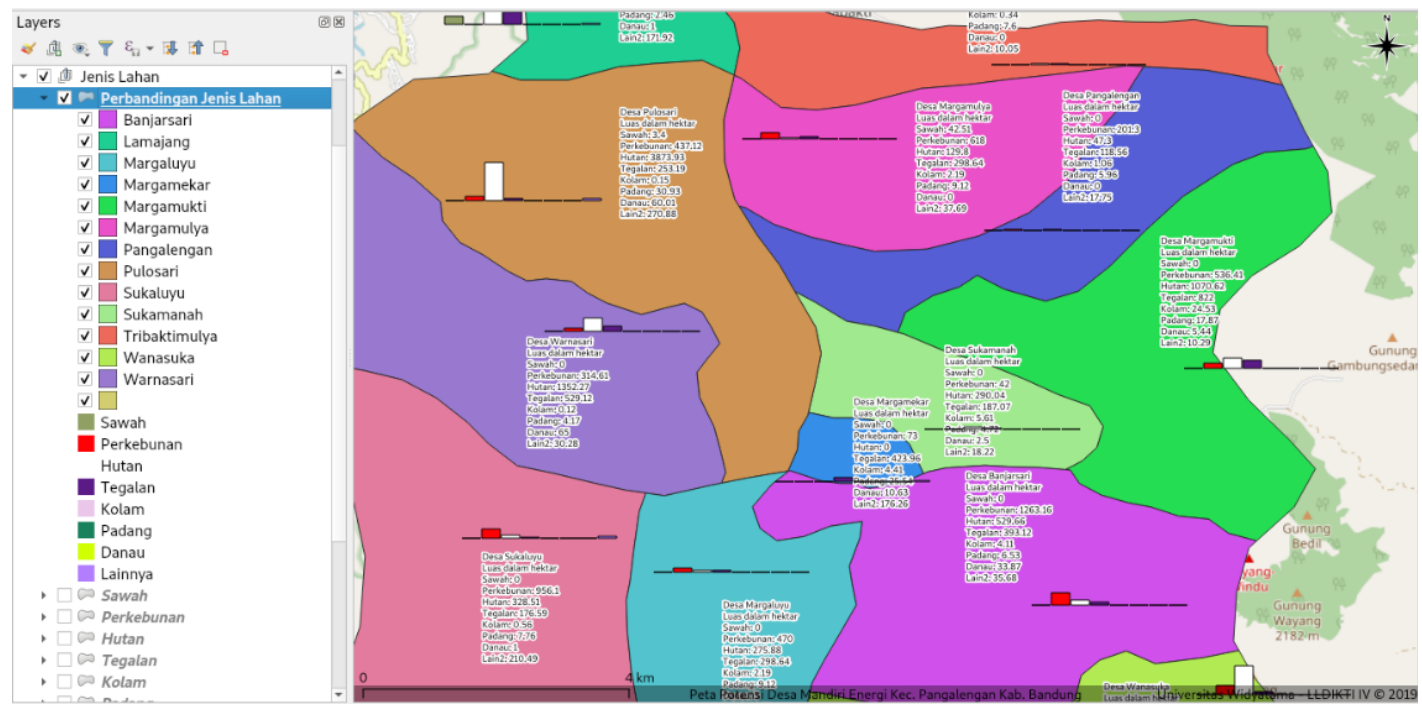

Gambar 6. Peta grafik batang perbandingan jenis lahan di setiap desa

Seperti yang sudah dibahas sebelumnya bahwa salah satu komoditi terbesar di Kecamatan Pangalengan ini adalah hasil perkebunan, perkebunan ini dimiliki secara individu maupun oleh perusahaan perkebunan baik swasta maupun badan usaha milik negara, pada Gambar 7. dapat digambarkan luasnya perkebunan secara keseluruhan di setiap desa di Kecamatan Pangalengan, sebagai contoh tampak pada peta Desa Banjarsari dengan warna polygon merah tua menandakan bahwa Desa Banjarsari ini memiliki areal 1263.16 hektar perkebunan paling luas di Kecamatan Pangalengan. 


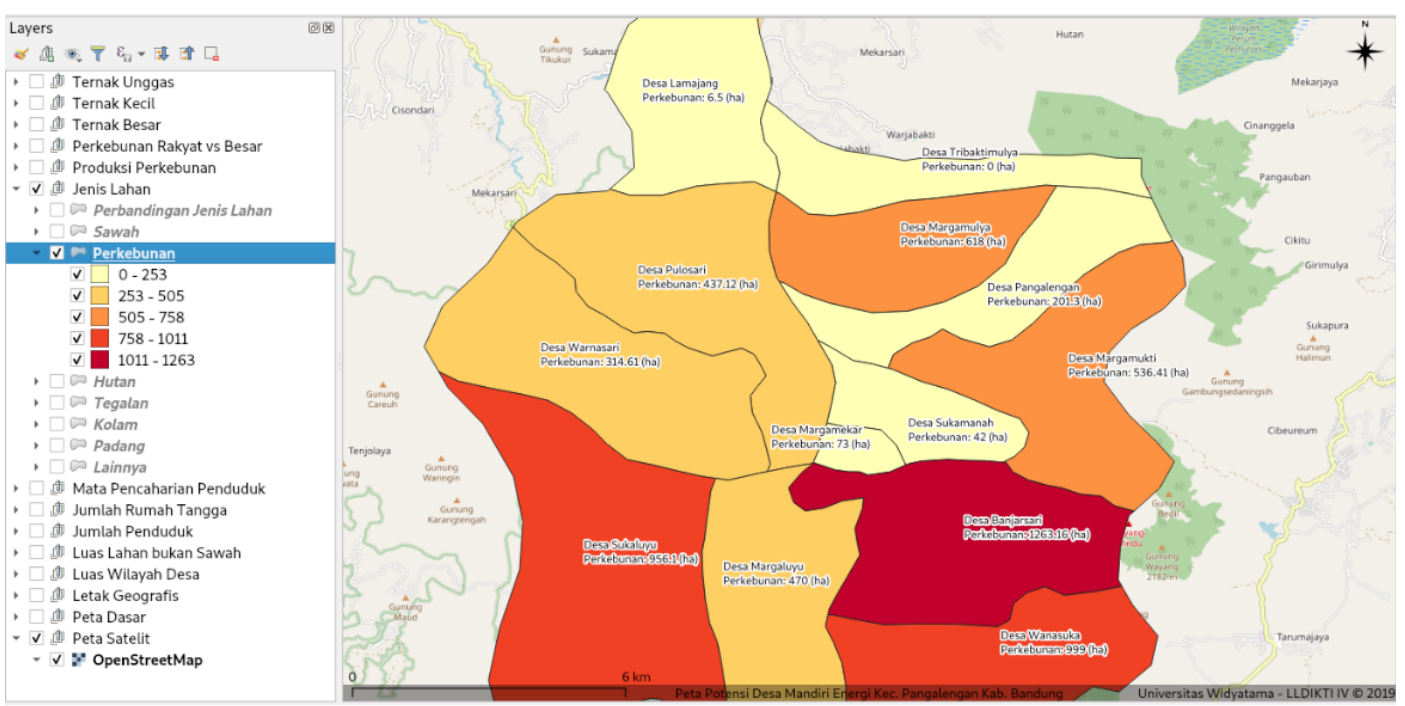

Gambar 7. Peta sebaran jenis lahan perkebunan di setiap desa

Perkebunan kopi di Kecamatan Pangalengan menjadi komoditas utama selain perkebunan teh, perkebunan cengkeh, pertanian hortikultura seperti kentang, wortel, lobak dan sebagainya, yang biasanya umur penanaman hortikultura tidak lebih dari 4 bulan sangat pendek biasanya akarnya pendek dan tidak baik bagi kekuatan tanah, disisi lain perkebunan kopi sangat baik bagi kesuburan tanah dan usia produktif pohon kopi bisa 8 sampai dengan 10 tahun, tampak pada Gambar 8. merupakan peta sebaran luas penanaman pohon, tampak pada Gambar 8. Desa Pulosari berwarna merah tua mempunyai luas terbesar 441 hektar, sedangkan desa-desa lainnya yang berwarna lebih pudar menandakan luas penanaman pohon kopi yang semakin kecil.

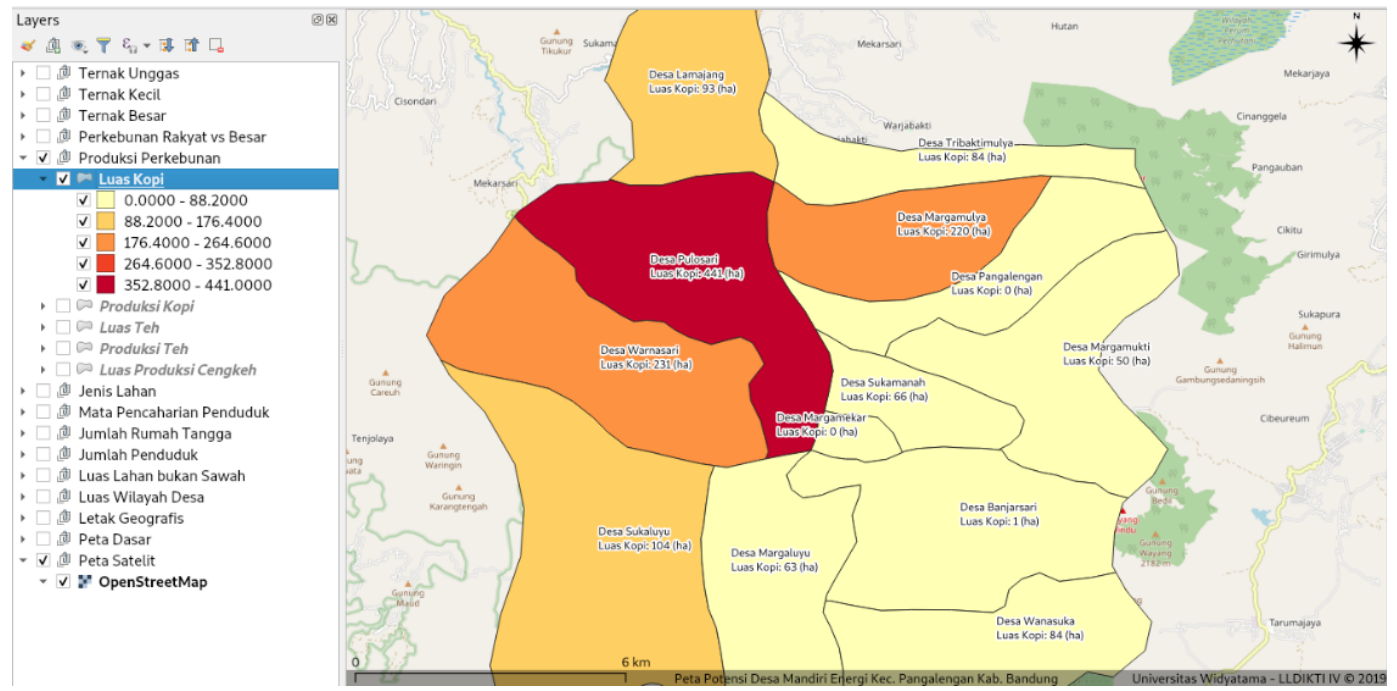

Gambar 8. Peta sebaran luas perkebunan kopi dalam hektar di setiap desa

Tampak pada Gambar 9. merupakan produksi kopi dalam kwintal, data ini sangat penting karena salah potensi energi biomassa yang bisa diolah menjadi energi adalah sampah perkebunan kopi seperti ranting pohon yang dipotong, biji kopi yang rusak yang tidak dipakai dan sebagainya, tampak pada peta bahwa Desa Pulosari dengan produksi 
kopi sebanyak 24.552 kwintal berwarna biru gelap, sedangkan desa-desa lainya berwarna putih menandakan produksinya tidak sebanyak Desa Pulosari.

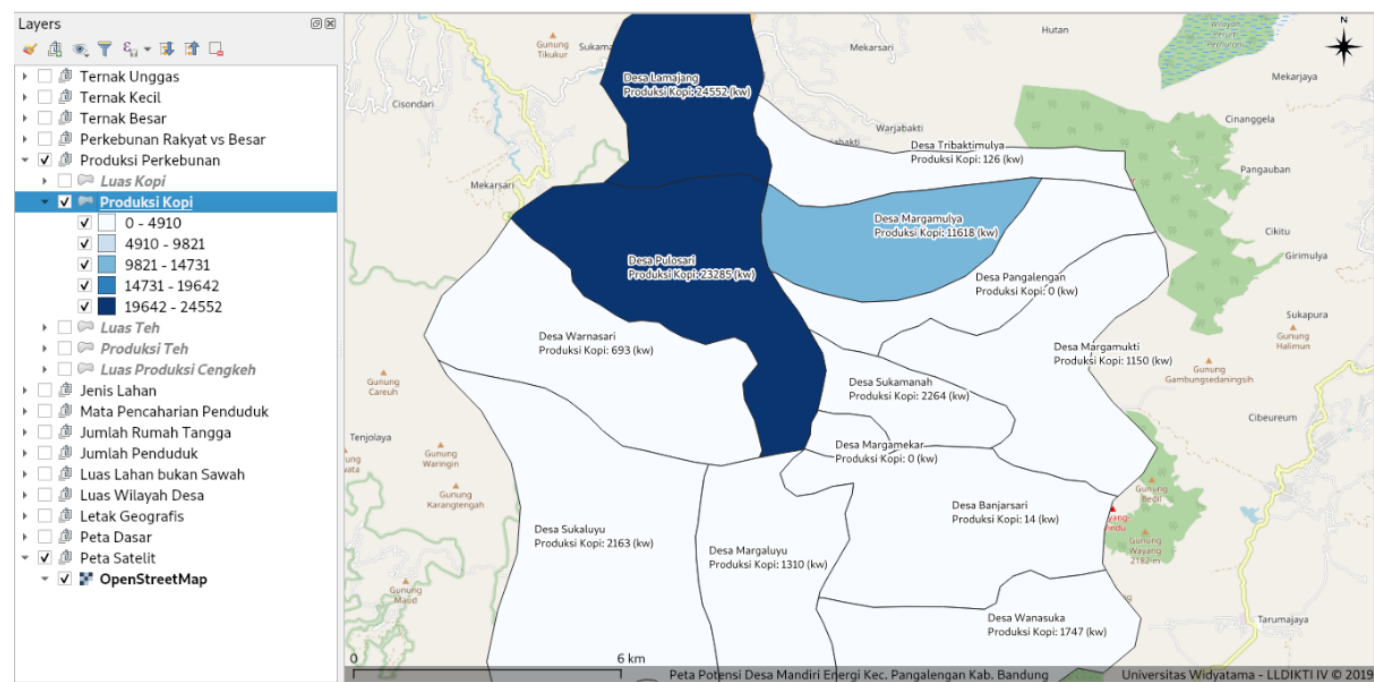

Gambar 9. Peta sebaran produksi perkebunan kopi dalam kwintal di setiap desa

Pada pada Gambar 10. merupakan peta sebaran luas areal perkebunan teh dalam hektar, perkebunan teh ini menjadi sangat penting dalam penentuan potensi energi berkelanjutan di Kecamatan Pangelangan, dari luasan perkebunan teh ini tiga kali lipat luasan perkebunan kopi, sehingga potensi energi biomassa diperkirakan dua atau tiga kali lipat dibanding perkebunan kopi, dalam Gambar 10 tampak ada dua desa yang memiliki areal perkebunan teh yang sangat luas yaitu Desa Banjarsari seluas 1256 hektar dan Desa Sukaluyu seluas 1137 hektar, memang kedua desa ini ada di ketinggian 1500 sampai dengan 2500 meter di atas permukaan laut, sangat cocok untuk perkebunan teh dengan hasil produksi yang berkualitas.

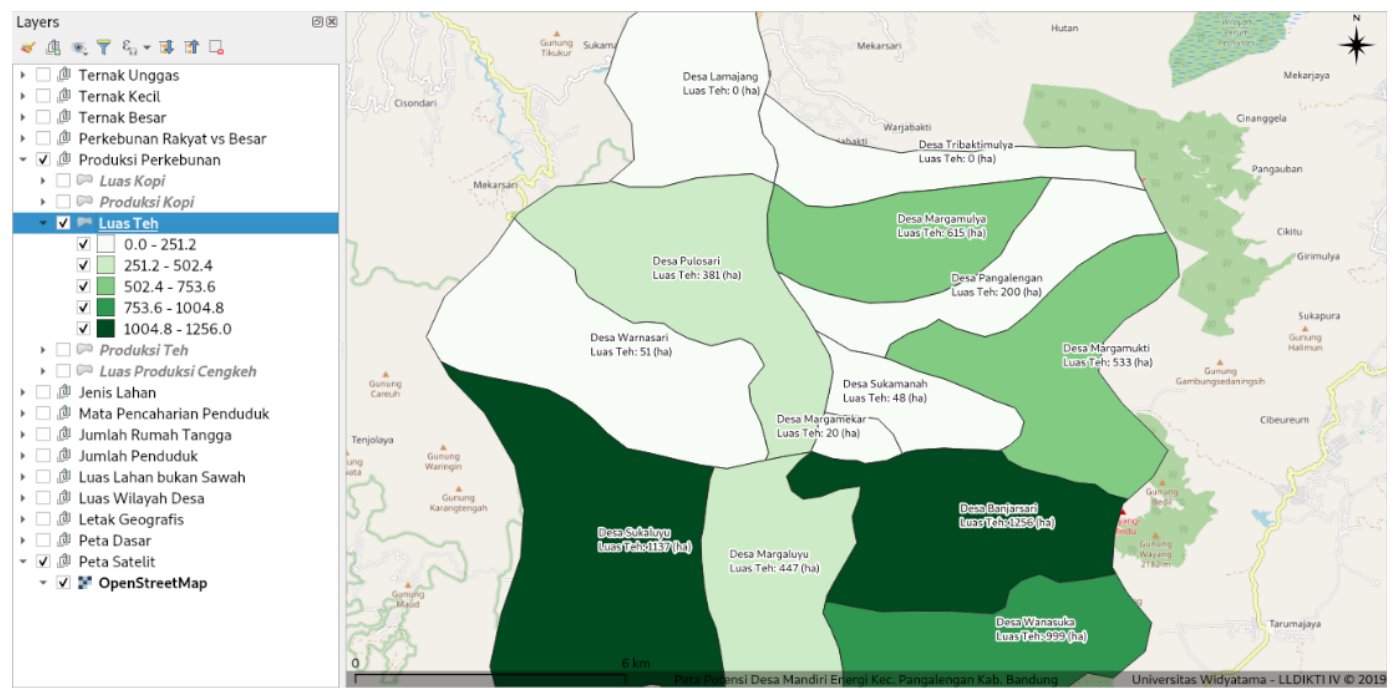

Gambar 10. Peta sebaran luas perkebunan teh dalam hektar di setiap desa

Seperti yang telah dibahas di Gambar 10. luas perkebunan teh, maka semakin luas perkebunan teh biasanya produksi teh semakin tinggi, tampak pada Gambar 11. merupakan 
besarnya produksi teh dalam kwintal di Kecamatan Pangalengan, perkebunan teh disinyalir mempunyai potensi energi biomassa yang besar, sampah-sampah biomassa hasil perkebunan teh seperti batang-batang dan daun yang mati bisa menjadi bahan sebagai energi biomassa, tetapi bila perkebunannya efektif dan efisien, tampak pada Gambar 11. ada informasi menarik bila kita bandingkan dengan Gambar 10., tampak pada Gambar 10. bahwa areal penanaman teh terluas itu ada di Desa Sukaluyu seluas 1137 hektar dan Desa Banjarsari seluas 1256 hektar, tapi kalau kita perhatikan hasil produksinya, Desa Sukaluyu 44.104 kwintal, Desa Banjarsari 117.405 kwintal, pada Gambar 11. kalau kita perhatikan bahwa warna polygon paling gelap adalah Desa Banjarsari, tapi polygon paling gelap sesudahnya yaitu Desa Wanasuka dengan total produksi 82.128 kwintal dengan luas areal perkebunan teh 999 hektar, bisa kita perhatikan bahwa produksi teh di desa Wanasuka ini sangat baik dibanding dengan Desa Sukaluyu dengan luas areal penanaman teh yang lebih luas.

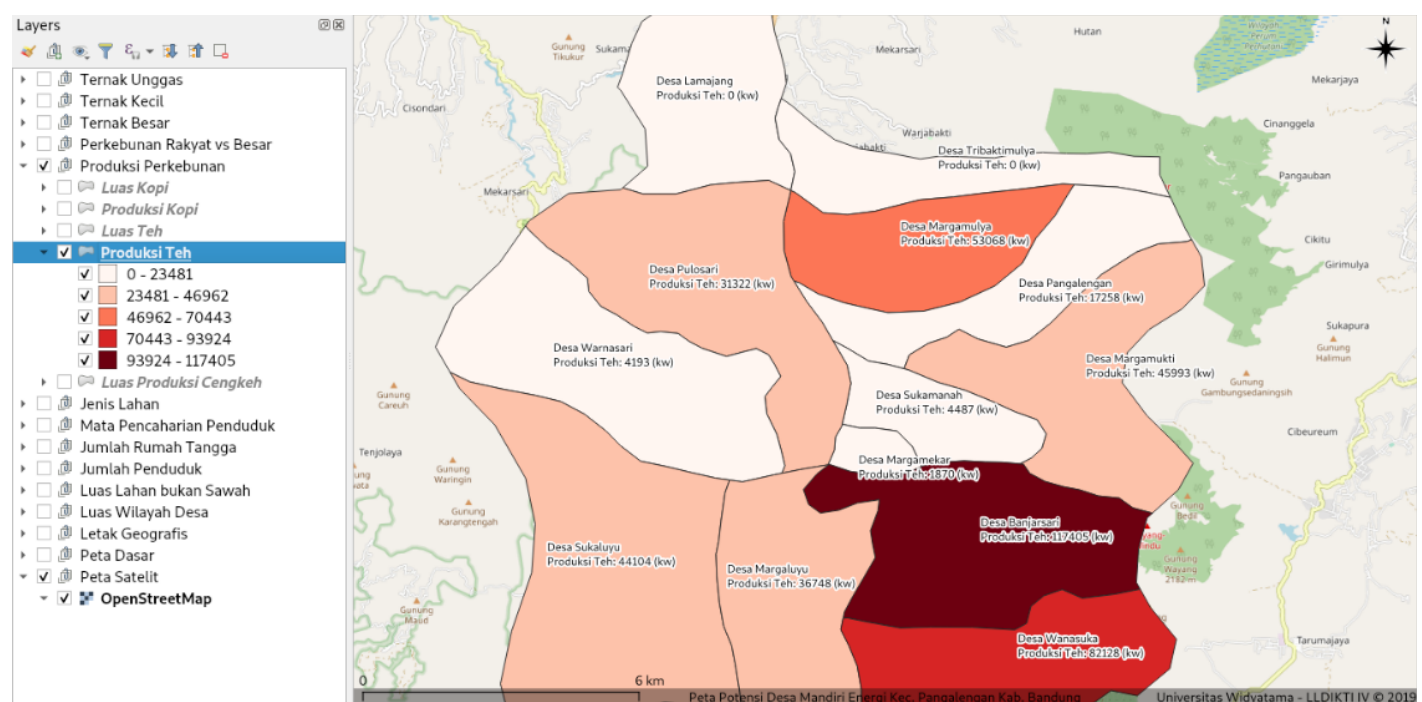

Gambar 11. Peta sebaran produksi perkebunan teh dalam kwintal di setiap desa

Hal yang penting di Kecamatan Pangalengan adalah peternakan sapi perah yang sudah ada dari zaman penjajahan Belanda, hampir semua sapi-sapi perah yang ada di Kecamatan Pangelangan ini jenis Friesien Holstein (FH) yang dulunya asalnya dari Belanda, sapinya besar-besar sehingga potensi kotoran sapi sebagai bahan energi menjadi biogas sangat besar, tetapi banyak peneliti perhatikan dilapangan instalasi reaktor biogas belum sempurna, sehingga potensi energi yang dihasilkan tidak terlalu besar, tampak pada Gambar 12. perbandingan ternak besar antar sapi perah, sapi non perah, kerbau dan kuda, sapi perah dengan grafik batang warnah merah mendominasi peternakan besar di Kecamatan Pangalengan. 


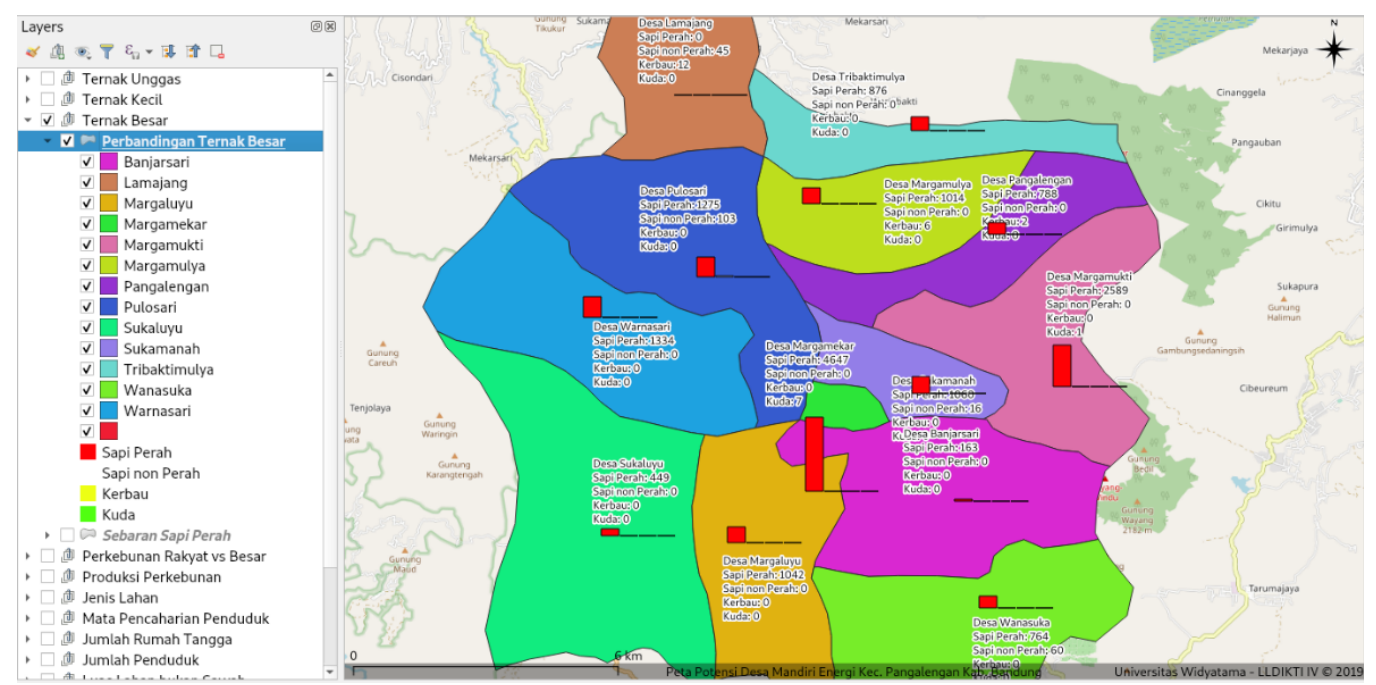

Gambar 12. Peta grafik batang perbandingan ternak besar : sapi perah, sapi non perah, kerbau dan kuda di setiap desa

Pada Gambar 13, tampak bahwa sebaran peternak sapi perah tersebar hampir di seluruh desa-desa di Kecamatan Pangelangan, paling besar ada di Desa Margamekar sejumlah 4647 ekor sapi perah dengan warna polygon merah tua menandakan paling banyak, kecuali Desa Lamajang tidak ada peternakan sapi, kemungkinan alasannya adalah faktor ketinggian Desa Lamajang di bawah 1000 meter, dimana memang peternakan sapi perah khususnya jenis Friesien Holstein (FH) membutuhkan ketinggian diatas 1000 meter baiknya, karena sapi-sapi perah import ini membutuhkan cuaca yang dingin dibawah 20 derajat celcius.

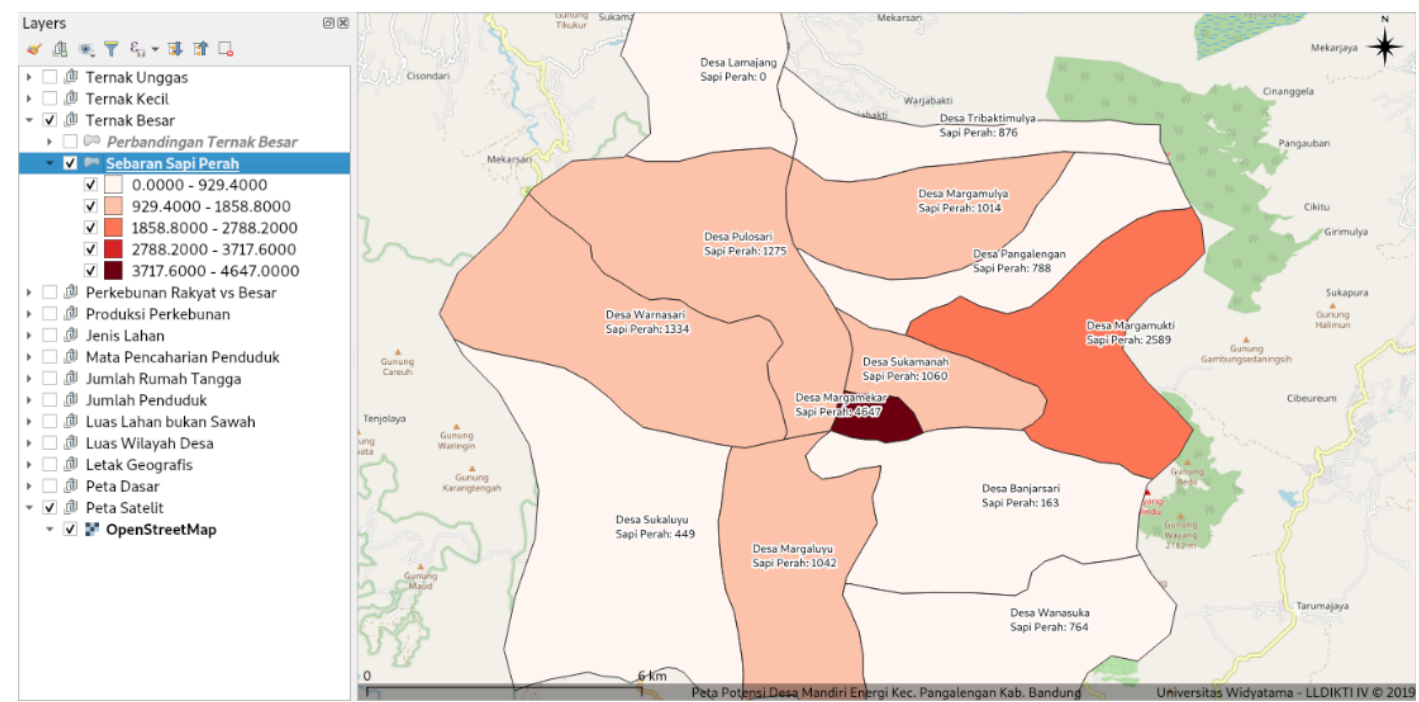

Gambar 13. Peta sebaran banyaknya sapi perah di setiap desa

\section{Kesimpulan}

Hasil keluaran sistem ada sejumlah 43 indikasi geografis, maka dapat disimpulkan bahwa, setiap desa di Kecamatan Pangalengan mempunyai keunikan dan kekhasan 
masing-masing, karena banyak faktor seperti ketinggian, kelompok pertanian, kelompok perternakan, perkebunan rakyat maupun perkebunan besar/negara.

Peternakan sapi yang dimiliki secara individu yang hampir tersebar di semua desa kecuali desa Lamajang, setiap peternak hampir memiliki reaktor biogas tetapi pengelolaan tidak maksimal sehingga hasil biogas tidak terlalu signifikan terhadap rumah tangga, bahkan lebih baik membeli gas melon $3 \mathrm{~kg}$ untuk memenuhi kebutuhan rumah tangga.

Perkebunan rakyat yang tersebar hampir disetiap desa di Kecamatan Pangalengan, ada potensi energi biomassa, sampah serpihan atau hasil kayu yang dibuang, belum dapat dimanfaatkan secara maksimal untuk proses biomassa, baik proses gasifikasi maupun reaktor fermentasi biomassa, masih digunakan secara biasanya dengan membakar langsung di setiap dapur yang mempunyai alat pembakar kayu tradisional (hawu).

Ada beberapa danau atau situ besar di Kecamatan Pangalengan, seperti situ Cileunca yang aliran airnya digunakan oleh sekitar 3 perusahaan listrik negara (Indonesia Power) sampai di daerah Cikalong, hasil energi yang dihasilkan cukup besar dengan daftar sebagai berikut : Sub Unit PLTA Plengan 6,87 MW, Sub Unit PLTA Lamajan 19,56 MW, Sub Unit PLTA Cikalong 19,20 MW, dengan besarnya daya terpasang setiap PLTA ini sepertinya Kecamatan Pangalengan harusnya semua desanya teraliri listrik. Juga ada PLTU yang dihasilkan oleh Gunung Windu atau Wayang di Desa Banjarsari.

Luasnya perkebunan besar/negara yang beroperasi di Kecamatan Pangalengan ratusan hektar, perkebunan teh dan kopi mendominasi luasnya areal perkebunan di kecamatan ini, perkebunan lainnya seperti cengkeh, alpukat, jambu, kayu dan lain sebagainya ada tapi tidak seluas teh dan kopi, sehingga potensi energi biomassa di Kecamatan Pangalengan ini sangat potensial.

Disimpulkan bahwa Kecamatan Pangalengan mempunyai potensi desa mandiri energi, hasil alam yang melimpah tanah, air, dan udara, seharusnya pengelolaan energi di kecamatan ini harusnya lebih baik lagi, untuk sebaik-baiknya digunakan bagi kesejahteraan rakyat.

\section{Ucapan Terima Kasih}

Ucapan terima kasih peneliti sampaikan kepada masyarakat serta aparat desa-desa dan Kecamatan Pangalengan, Kementerian Ristek Dikti, LLDikti IV, Universitas Widyatama yang telah membantu penelitian ini.

\section{Daftar Pustaka}

[1] IRENA. Renewable Energy Technologies: Cost Analysis Series, Biomass For Power Generation. The International Renewable Energy Agency (IRENA). 2012;

[2] Nisha Sriram, Mohammad Shahidehpour. Renewable Biomass Energy. International Journal of Business, Economics and Management. IEEE. 2005;

[3] Donald L. Klass. Biomass for Renewable Energy And Fuels. Encyclopedia of Energy, published by Elsevier, Inc. r 2004;

[4] Abdeen Mustafa Omer. Biomass Energy Resources Utilisation And Waste Management. Journal of Agricultural Biotechnology and Sustainable Development Vol. 3(8), pp. 149 -170, October 2011;

[5] Sumit Sharma, Rajendra Meena, Amit Sharma, Pawan Kumar Goyal. Biomass Conversion Technologies for Renewable Energy and Fuels. IOSR Journal of Mechanical and Civil Engineering (IOSR-JMCE). 2014;

[6] C. . R. Kothari (1990), Research Methodology Method \& Techniques (Second Revised Edition). New Delhi: New Age International; 
[7] Jonathan Campbell, Michael Shin. Essentials to Geographic Information Systems. Flat World Knowledge, Inc. 2011;

[8] Burrough P. Principle of Geographical Information System for Land Resources Assesment. Oxford, Claredon Press. 1986;

[9] Stephanie Rogers, Patricia Vivas. A study on the use of Geographical Information Systems (GIS) for the creation of addressing systems. Universal Postal Union. 2014;

[10] Y. Sulistiyanto, Sustiyah, S. Zubaidah, B. Satata (2016), Pemanfaatan Kotoran Sapi Sebagai Sumber Biogas Rumah Tangga Di Kabupaten Pulang Pisau Provinsi Kalimantan Tengah, Jurnal Udayana Mengabdi, Volume 15 Nomor 2. 